\title{
Edutainment Learning Model Based on Detective Thinking to Increase the Critical Thinking of Elementary School Children
}

\author{
Siwi Purwanti \\ siwi.purwanti@pgsd.uad.ac.id \\ Pendidikan Guru Sekolah Dasar, Universitas Ahmad Dahlan
}

\begin{abstract}
This paper aims to explain that the edutainment learning model based on detective thinking is a model that can improve critical thinking of elementary school children. Critical thinking skills are needed by children in the present era. When children can think critically, they can solve problems in everyday life. The ability to think critically can be honed through learning Natural Science in schools by edutainment based on detective thinking model. Edutainment based on detective thinking model is a learning model that combines the principles of scientific inquiry and research with the entertainment content. Hopefully with the entertainment content, students will be more interested, learning becomes fun, and students' critical thinking skills will be increased.
\end{abstract}

Keywords: Edutainment learning model based on detective thinking, critical thinking, elementary school students

\section{Introduction}

The background of this study is the low critical thinking ability of elementary school students in Natural Science subject. Natural Science subject is one of the compulsory subjects in elementary school. This subject is very related to everyday life, and also close to students. For this reason, students must have comprehensive and critical thinking skills so that they can well studied the Natural science subject. Moreover, the 2013 curriculum, which is studentcentered, also emphasizes on the ability of HOTS (Higher Order Thingking Skills) in which there is critical thinking. The ability to think critically is very important for elementary school children to have their mental activities. As Baker[1] explained that critical thinking is used by a person in the process of mental activities such as identifying the problems center and assumptions in an argument, making the correct conclusions from the data, interpreting whether conclusions are guaranteed based on the data provided, and evaluating evidence or authority.

To think critically, students need stimulation from the teacher. Stimulation can be done through a learning approach. According to Sanjaya[2], learning approach is a point of view or starting point regarding the occurrence of learning processes in general based on a particular theoretical scope. The choice of approach is a very important thing in order to achieve the learning objectives.

One learning approach that can improve critical thinking of elementary school children is edutainment learning model based on detective thinking. A learning model that combines elements of entertainment and education. As stated by Priyambodo and Situmorang[3], the concept of "edutainment" is a form of alignment of two terms, i.e. "education" and "entertainment". Furthermore, Priyambodo and Situmorang[3] stated that the integration and alignment of this interdisciplinary concept aims to balance the presentation of learning 
challenges with the stimuli provision in the form of entertainment elements that can foster enthusiasm, cheerfulness, and self-confidence among students. For this reason, this study discusses one of the learning models that can be used to improve critical thinking of elementary school students, which is the edutainment learning model based on detective thinking.

\section{Reference citations}

A. Edutainment Learning Model Based on Detective Thinking

Hamruni[4] connoted in the edutainment learning that learners is the center of the learning process. Edutainmment is a learning process designed to make education and entertainment to be combined harmonically in order to make fun learning[5]. The edutainment model based on detective thinking is a learning model that collaborates the principles of scientific inquiry and research with proportional entertainment content[3] .The principle of scientific inquiry and research must be trained early on, especially in elementary school students. The benefits of edutainment based on detective thinking according to Priyambodo \& Situmorang[3] are:

a. Developed based on the principles of constructivism and progressivism

b. Collaborate and integrate the principles of several models and learning methods

c. Implementing an inquiry approach

d. Developing process skills

e. Presenting direct experience

f. Forming teachers who are active, creative, and able to innovate

Furthermore, the shortcomings of an edutainment model based on detective thinking are also explained by Priyambodo \& Situmorang[3]

a. Careful planning is needed

b. Integration of entertainment content must be right

c. Improper questions can results in the mind's chaotic conception

d. Lack of students' awareness in the investigation

e. Requires environmental conditions that representative natural

f. Requires extra supervision from the teachers so that the children maximal in learning.

Based on the benefits and shortcomings, the teachers must be able to design learning well. When learning is carried out properly, then the learning objectives can be achieved optimally. Edutainment is a model facilitates students to be active in the learning process to find solution for social issues through critical thinking[6]. Teachers must also be able to properly resolve the shortcomings of the edutainment model, for example if this model requires careful planning, the teacher must prepare ahead of time so as to minimize the shortcomings that occur.

\section{B. Critical Thinking}

Critical thinking is one of the skills that elementary school students must have. Critical thinking is a process, that aiming to make reasonable decisions about what is believed and what is done[7]. Fisher[8] argued that critical thinking is a skilled activity, which can be done well or vice versa. Good critical thinking will fulfill a variety of intellectual standards, such as clarity, relevance, adequacy, and others. According to Ennis (in Filsaime [9]), critical thinking is a reflective way, which is reasonable or based on reason, focused to determine what must be believed and done. Based on these two opinions, it can be concluded that critical thinking is a skillful activity, which is reflective and reasonable to determine what will be done.

According to Enis (in Susanto[10]), there are several indicators related to the aspects of critical thinking, which are: 
1. Provide simple explanation, which includes:

a) focusing questions;

b) analyzing questions;

c) ask and answer about an explanation or question.

2. Building basic skills, which includes:

a) Considering whether sources can be trusted

b) Observing and considering an observation report

3. Summing up, which includes:

a) Deducing and considering the results of deduction

b) Inducing and considering the results of induction

c) Making and determine the value of consideration

4. Provide further explanation, including:

a) Defining terms and considerations of definitions in three dimensions.

b) Identifying assumptions

5. Organize strategies and tactics, which includes:

a) Determining actions

b) Interacting with others

Another opinion regarding indicators of critical thinking skills according to Wowo[11] are as follows:

1. Identifying the focus of the problem, questions, and conclusion.

2. Analyzing arguments.

3. Asking and answering classic questions or challenges

4. Defining the decision term and handle according to reason

5. Observing and assessing observation reports

6. Summarize and assessing decisions

7. Considering reasons without letting disagreements or doubts that disturbed the thought (think that is supposed to be right).

8. Integrating other abilities and position in making and maintaining decisions.

According to Wahidin (Mahanal[12]), there are several advantages gained from learning that emphasize the critical thinking process, which are:

a. learning is more economical, in which what is acquired and its teaching will last long in the students' mind

b. increase teachers and students' enthusiasm for learning

c. students are expected to have a scientific attitude

d. students have the ability to solve problems both during the teaching and learning process in class and when facing the real world.

C. Characteristics of Elementary School Students

According to Desmita[13], children of elementary school age have different characteristics with younger children. They like to play, move, work in groups, and love to do things directly. Therefore the teachers should develop learning that contains elements of the game, make students move in working and learning, and provide direct opportunities in learning.

Desmita[13] explained that teachers must do several things to be able to support the tasks of the development of elementary school age children, which are:

a. Create a peer environment that teaches physical skills 
b. Carry out learning that provides opportunities for students to learn to get along, and work with peers, so that their social personality can develops

c. Develop learning activities that provide concrete or direct experience in building concepts

d. Carry out learning that can develop values so that students are able to determine stable choices and become a hold of themselves.

\section{Literature Review}

Research conducted by Wijayanti[14], on "Critical Thinking Analysis of the $5^{\text {th }}$ Grade Elementary School Students in Learning" has the aim of knowing elementary school students' critical thinking skills. The object of this research is the fifth grade students in elementary school number 1,2, and 3 Kaliuntu. The results of the research by Wijayanti[14] showed that the average critical thinking ability in 1 Kaliuntu Elementary School is 17.95, which is low; 2 Kaliuntu Elementary School is 17, which is low; and 3 Kaliuntu Elementary School is 9.46, which is very low. From the results of the research, it can be concluded that learning methods are needed in order to improve students' critical thinking skills.

Agustia[15] conducted a research that examined the concept of edutainment learning models in elementary school. From the results of his research, it can be concluded that the concept of edutainment is actually exist in the 2013 Curriculum principle, which is now being implemented in elementary schools. Students as the center in learning, spatial planning, conditioning the learning process into something fun are important things for teachers to do. Therefore, students feel relaxed and enjoy the learning process in the hope that learning outcomes will be good too.

The concept of edutainment based on detective thingking is also discussed by Priyambodo $\&$ Situmorang[3] which explained that this model tries to generate challenges in the form of problems that students must solve, also must generate elements of pleasure. The existence of these three literature reviews further adds to the reference that children's critical thinking skills can be related to the learning model, i.e. edutainment based on detective thingking.

\section{Methodology}

The method in writing this paper was library research by conducting a theoretical study of books, journals, and relevant research results. This study start from the study of Edutainment Learning Model Based on Detective Thinking, critical thinking skills, and the study on elementary school children. Then formulated the concept regarding the learning model based on detective thinking to improve critical thinking of elementary school children. Data analysis techniques were carried out by evaluating and reflecting the results of theoretical studies and relevant research. The concepts that have been studied are expected to later be applied in classroom learning.

\section{Results and Discussion \\ The Concept of Edutainment Learning Model Based on Detective Thinking to Improve the Critical Thinking}

The syntax of the edutainment model based on detective thinking (Priyambodo \& Situmorang[3] are as follows:

1. Pre-lab activity 
The pre-lab activity aims to provide training for students regarding the basics of the investigation as well as a feedback medium for the teachers to determine the students' ability and readiness level before implementing the learning. Pre-lab activities include:

a. Orientation and apperception that aims to prepare students for the next stage.

b. Explanations related to learning objectives, competency targets, scope of material, and learning methods to be used.

c. Division of groups

The groups formation is carried out heterogeneously along with the affirmation accompanied by reaffirmation regarding the investigation mechanism that will be carried out through action/characterization activities (role playing). The teachers also give confidence to students that humans who have a concern for the problems that occur both in the social environment and in the natural environment, especially strong desire to solve it, are humans who has the soul, nature, and character as a scientist. The teachers treat students like real scientists so that in their hearts there is awareness and confidence to try to contribute in the form of thoughts, efforts, and knowledge in order to overcome the problems that exist.

2. Multiple leading Questioning

This stage is the activity of giving "guiding questions" by the teachers regarding the scope of the study object to be studied. From the guiding question, the teachers then direct students to respond in the form of relevant "critical questions." Critical questions will later be used as guidelines in carrying out the investigation.

3. Hypothesis and experiment analysis

The stage of hypothesis and experiment analysis include three things, which are:

a. Formulation of hypothesis

The formulation of the hypothesis provides an overview and reference to students regarding what data they need, where the investigation will be conducted, what tools are needed, how to investigate, what are the possible answers that must be obtained, how to get them, where must find data and information, how to draw conclusions that must be formulated, and so on.

b. Investigation analysis

Investigation analysis is carried out continuously with the formulation of hypothesis. This activity is the basis for determining the design of the investigation based on the analysis of the relationship or position or interaction between the research variables that have been established. In other words, the investigation analysis is an analysis related to the relationship between the research variables contained in the hypothesis formulation to underlie the determination of research designs.

c. Experiment Analysis

Experiment analysis is the activity of planning, designing, and determining the design of the investigation concretely based on considerations that have been synthesized during the investigation analysis.

4. Empirical of Inductive

The empirical of inductive stage consists of three things, which are:

a. Collection of data and information

The teacher guides every student who has joined the investigation group to work on collecting the data and information. If students lack experience and skills related to scientific investigation, the learning process can be done by guided inquiry.

b. Analysis of data and information 
Analysis of data and information is carried out by students by working together in their respective groups. The teacher can also provide assistance in the form of giving followup guidance questions.

c. Conclusions

Conclusions are drawn by connecting the premises obtained from data and information analysis. Conclusions are used to confirm the correctness of the hypothesis formulation set at the beginning of the investigation. Conclusions are drawn by students through discussion activities assisted by the teacher.

d. Preparation of report

The report is prepared by students in every group and contains information related to a series of investigation activities that have been carried out including report on the investigation results, data analysis and discussion, conclusions explanation, and constraints experienced during the implementation. In the process of the report preparation, students can utilize a variety of references to support (strengthen) concepts or theories that have been synthesized. The teachers can also apply two types of reporting in the form of temporary reports and original reports which are then collected as assessment material.

\section{Communication and Reflection}

This fifth stage consists of three things, which are:

a. Presentations and discussions

The results of the investigation are then presented in communicative class discussion forums. Each group representative alternately present in front of the class to explain the results of the investigation activities according to their respective themes. Although the research themes between groups are different but remains under the big theme that covers the whole themes in every group. Students from other groups can also provide confirmation and even objections to the presentation results to create a productive climate of discussion. Even if the debate climate is created, this condition is not directed to merely act of "being different" but is directed to find common ground that can be accepted.

\section{b. Reflection and generalization}

The teachers guide students to reflect on the entire series of investigation activities that have been carried out, analyzes the constraints and difficulties experienced while at the same time formulating improvements for the implementation of further investigations. Students are also directed to attract the core.

Of the five stages that have been explained by Priyambodo and Situmorang[3] the points that can improve students' critical thinking are:

a. Step number 2 in the form of a Multiple leading questioning. The critical questions raised by students here will certainly make students be critical thinking.

b. Step number 3 is hypothesis and experiment analysis. The hypothesis is a temporary answer to the research problem formulation, in which the formulation of the research problem has been stated in the form of question. Said to be temporary because the answers given are just based on relevant theories, not yet based on empirical facts obtained through data collection[16]. When a student tries to formulate a temporary answer, there is a thought process in it. Experiment analysis is a stage that can also lead students to critical thinking.

c. Empirical inductive. At the data collection stage, students will be trained to think about what data is written, obtained related to their investigation. Students will be able to 
practice critical thinking skills at this stage. When there are students still lack in mastering, the teachers can provide guidance. The conclusion formulation stage also trains students to critical thinking skills, because students must link whether the hypothesis that has been made at the beginning, accepted or rejected.

Teachers in the class must always develop a good learning model. Good learning should be able to explain how students should learn and think. Learning not only memorizes general facts and concepts of learning material as happened in the industrial era[17]. In learning, students must strive to develop critical thinking, it takes carefulness, new ideas with open mind. Although it is not easy but must be carried out in an effort to develop thinking skills[8]. The concept of an edutainment learning model based on detective thinking to improve critical thinking can be seen in Figure 1.

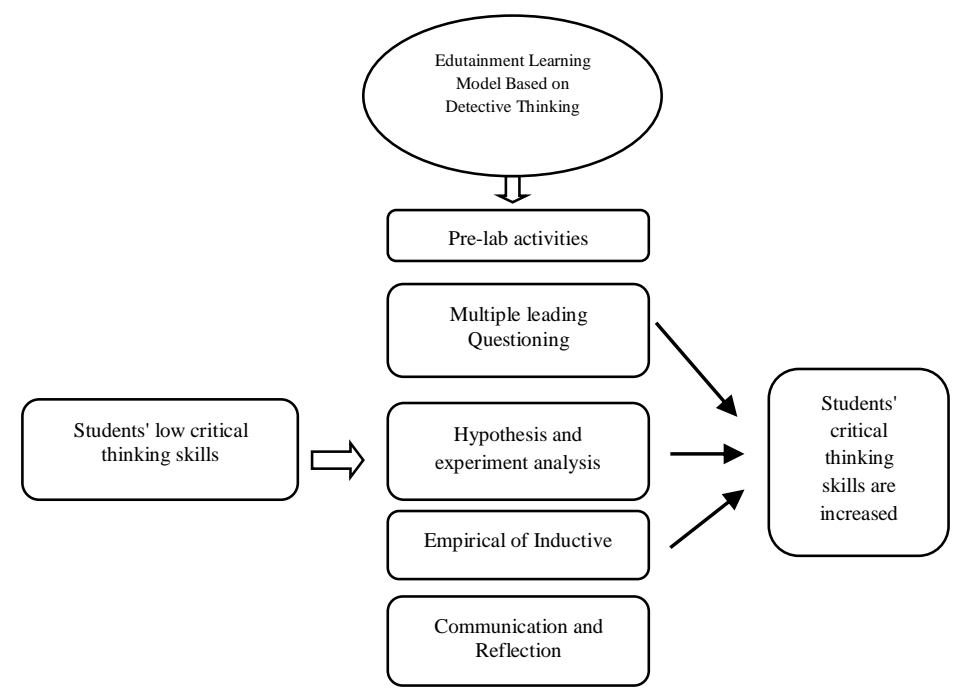

Figure 1. The Idea of Edutainment Learning Model Based on Detective Thinking to Improve Critical Thinking

\section{Conclusion}

It is important for teachers to master the class, especially in the selection of learning models. The learning model used must be student-centered, fun, and direct students to critical thinking. One of the learning model concepts that can be used to improve students' critical thinking is the edutainment learning model based on detective thinking. The model contains 5 stages, i.e. pre-lab activity, multiple leading questioning, hypothesis and experiment analysis, empirical of inductive, communication and reflection. From the 5 stages of the model, there are 3 stages that can lead students to critical thinking, i.e. multiple leading questioning, hypothesis and experiment analysis, and empirical of inductive. 


\section{References}

[1] M. Baker, Relationships Between Critical and Creative Thinking. Texas: Tech University Press, 1991.

[2] W. Sanjaya, Perencanaan dan Desain Sistem Pembelajaran. Jakarta: Kencana, 2008.

[3] R. P. S. Panggih Priyambodo, Antigen Antibodi Pembelajaran. Yogyakarta: Pustaka Pelajar, 2017.

[4] Hamruni, Edutainment dalam Pendidikan Islam dan Teori-Teori Pembelajaran Quantum. Yogyakarta: Fakultas Tarbiyah UIN Sunan Kalijaga Yogyakarta, 2009.

[5] N. M. Korina Katsaliaki, "Edutainment for Sustainable Development: A Survey of Games in the Field," SAGE Publ., 2014.

[6] M. Fadlillah, Edutainment Anak Usia Dini Menciptakan Pembelajaran Menarik, Kreatif, dan Menyenangkan. Jakarta: Prenadamedia Group, 2013.

[7] R. H. Ennis, Critical Thingking. New Jersey: Prentice Hall Inc, 1996.

[8] A. Fisher, Berfikir Sebuah Pengantar. Jakarta: Erlangga, 2009.

[9] D. K. Filsaime, Menguak Rahasia Berpikir Kritis dan Kreatif. Jakarta: Prestasi Pustakakarya, 2008.

[10] A. Susanto, Teori Belajar dan Pembelajaran di Sekolah Dasar. Jakarta: Kencana, 2013.

[11] W. S. Kuswana, Taksonomi Berpikir. Bandung: PT Remaja Rosdakarya, 2011.

[12] S. Z. Susriyati Mahanal, "Penerapan Pembelajaran Berdasarkan Masalah dengan Strategi Kooperatif STAD pada mata Pelajaran Sains untuk Meningkatkan Kemampuan Berfikir Siswa Kelas V MI Jenderal Sudirman Malang," J. Penelit. Kependidikan, vol. 1, pp. 43-53, 2010.

[13] Desmita, Psikologi Perkembangan Peserta Didik. Bandung: PT Remaja Rosdakarya, 2014.

[14] M. Wijayanti, Pudjawan, "Analisis Kemampuan Berpikir Kritis Siswa Kelas V Dalam Pembelajaran IPA di 3 SD Gugus X Kecamatan Buleleng,” J. PGSD Univ. Pendidik. Ganesha Jur. PGSD, vol. 3 No: 1, 2015.

[15] N. R. Agustia, "Konsep Pembelajaran Berbasis Edutainment Dalam Kurikulum SD/MI," UIN Sunankalijaga Yogyakarta, 2013.

[16] Sugiyono, Metode Penelitian Kuantitatif, Kualitatif dan R\&D. Bandung: Alfabeta, 2013.

[17] C. F. Bernie Trilling, 21st Century Skills. Learning For Life In Our Times. San Fransisco: JosseyBass, 2009. 